\title{
The Estimation of Inositol in Animal Tissues
}

By B. S. PLATT AND GERTRUDE E. GLOCK, Nutrition Building, National Institute for Medical
Research, Mill Hill, N.W. 7, and the Lister Institute of Preventive Medicine, Chelsea Bridge Road, S.W. 1

'(Received 31 July 1943)

Inositol occurs in animal tissues in both free and combined forms. The occurrence of water-soluble combined inositol was first suggested by Rosenberger [1908a,b, 1910]. Comparing the inositol contents of fresh rabbit muscle and commercial beef muscle, he came to the conclusion that animal tissues contain 'inositogen'. This may be identical with the 'tyrophenosit', of Danileffski [1884], who reported, without giving data, a considerable increase in the inositol content of mice after 6 days' autolysis at $37^{\circ}$ in the presence of $\mathrm{CHCl}_{3}$. Needham [1923] found that the skeletal muscle of a freshly killed rabbit contained only one-half the amount of inositol found in that of a rabbit killed 2 days previous to the estimation. An increase in the free inositol content of the skeletal muscle of rats occurred after autolysis of the tissues [Needham, 1924]. Winter [1934], working on cardiac muscle of dogs, postulated the occurrence of three forms of inositol in animal tissues: 'free' inositol, determined after $\frac{1}{2} \mathrm{hr}$. boiling with $10 \% \mathrm{KOH}$; 'combined' inositol, determined after $5 \mathrm{hr}$. boiling with $10 \%$ $\mathrm{KOH}$, and 'newly formed' inositol, liberated after incubation at $37^{\circ}$ in nitrogen. The cardiac muscle of the sheep, ox and pig contained no 'combined' inositol [Winter, 1940]. It is doubtful, however, whether much significance can be attached to any of Winter's results; owing to the unreliability of the chemical methods he employed. Woolley [1941 $a$ ] obtained inositol after acid or alkaline hydrolysis of an ethanol-insoluble, $\mathrm{H}_{2} \mathrm{O}$-soluble, non-dialyzable substance isolated from liver. This was considered to be probably a phosphoric acid ester of inositol. Rapoport [1940] found that in bird and turtle erythrocytes a large proportion of the organic acidsoluble $\mathrm{P}$ is present in the form of phytic acid. Besides being present in animal tissues in watersoluble combined forms, inositol also occurs in brain and spinal cord bound in a phosphatide fraction. Folch \& Woolley [1942] isolated inositol from an acid hydrolysate of brain cephalin, and found that it constituted up to $10 \%$ of this phosphatide fraction and amounted to as much as $0.4 \%$ of the weight of the brain.

It is evident that further work is required to elucidate the nature of the water-soluble combined forms of inositol in the animal body and the methods of breakdown and significance of both water-soluble and water-insoluble combined forms.
Recent developments have, in fact, followed on the application of a microbiological technique [Williams, Stout, Mitchell \& McMahan, 1941; Woolley, 1942]. The chemical methods at present available for the estimation of inositol in biological material [see Needham, 1923, 1926; Winter, 1934, 1940; Young, $1934 a, b$; and Gregory, 1935] are, however, tedious, lengthy and involve the use of relatively large amounts of tissues. The method to be described is much quicker than previous ones and possesses several other advantages, including improvements in the extraction of inositol from tissues, the removal of interfering substances by ion exchange materials and the estimation of inositol, without isolation, by oxidation with periodic acid.

\section{METHODS}

\section{Principle of the method of estimation}

Dried tissue is extracted with water and the fractions insoluble in $70 \%$ acetone and soluble in ether both removed from the aqueous extract. Glucose is then removed by yeast fermentation and both acidic and basic substances present in the extract removed by adsorption on a mixture of ion exchange adsorbents. The free inositol present in the extract is then quantitatively oxidized with $\mathrm{HIO}_{4}$, the excess $\mathrm{HIO}_{4}$ being estimated iodometrically. Suitable corrections are applied for any $\mathrm{HIO}_{4}$ used in oxidizing the glycerol which may be present in the extract at this stage.

Water-soluble combined inositol is determined after acid hydrolysis of the aqueous extract.

\section{Experimental}

Preparation of tissue for extraction. As soon as possible after death, the tissue is removed from the animal, sectioned on a freezing microtome and the sections dried in thin layers in Petri dishes in vacuo in the cold room over silica gel. Drying is completed in an oven at $110^{\circ}$, after which the material is powdered and kept in the cold until analyzed. The water content of another portion of the same tissue is determined by drying to constant weight at $110^{\circ}$.

Extraction of inositol. An amount of dried powdered tissue containing approximately $0 \cdot 5-1.0 \mathrm{mg}$. inositol (i.e. 1.0-2.0 g. dry skeletal muscle powder) is brought to the boil with $50 \mathrm{ml}$. distilled water, filtered under reduced pressure through a small plug of cotton-wool in a funnel, and the vessel and filter washed with two portions of $5 \mathrm{ml}$. of distilled water. This process is repeated twice, the three 
extracts pooled and evaporated to about $50 \mathrm{ml}$., and acetone added to give a final concentration of $70 \%$. The precipitate is filtered off and the acetone removed from the filtrate by distillation. The extract is evaporated down to about $25 \mathrm{ml}$. and extracted with ether. The ether extract is washed once with about $20 \mathrm{ml}$. distilled water, and the washings added to the aqueous residue, which is then concentrated to approximately $30 \mathrm{ml}$. If it is desired to estimate the 'combined' water-soluble inositol as well as the 'free' inositol the aqueous extract can be divided into two portions and one hydrolyzed as described below.

Removal of glucose. The only satisfactory method for the removal of glucose was found to be yeast fermentation, as used by Young [1934a]. Since some products of glucose fermentation have to be removed on the ion exchange adsorbents, the fermentation stage was carried out before the adsorption.

A washed yeast suspension is prepared by shaking one part by weight of pressed baker's yeast with five parts of distilled water, and centrifuging; this process is repeated four times and the suspension of washed yeast then made up to the original volume with distilled water. The suspension is prepared fresh each day and its potency tested by incubating $2 \mathrm{ml}$. with $25 \mathrm{ml}$. glucose solution (containing $5 \mathrm{mg}$. glucose) for $10 \mathrm{~min}$. at $37^{\circ}$, and estimating the reducing power of the supernatant fluid, obtained by centrifuging, by Hagedorn \& Jensen's ferricyanide method, a blank being set up at the same time with yeast suspension and water only.

The tissue extract is incubated at $37^{\circ}$ with $2 \mathrm{ml}$. of the yeast suspension for $10 \mathrm{~min}$. and then centrifuged. The supernatant liquid is siphoned into a boiling tube and the yeast washed twice by centrifuging with $10 \mathrm{ml}$. portions of distilled water, the washing being kept separate from the main supernatant fluid for the subsequent adsorption.

Preparation of ion exchange materials and the removal of interfering substances from tissue extracts. After treatment with yeast, the extract is purified by the use of ion exchange materials, with a carbonaceous zeolite for cation exchanges and 'M.P.D. Resin' as an acid adsorbent. Both these are obtainable from Permutit Company, Limited. A brief account of the use of these substances for the purification of muscle extracts has been published [Platt \& Glock, 1942]. The removal of creatine and creatinine from muscle extracts by this method proved to be much more efficient than by the precipitation technique of West \& Petersen [1932] with $\mathrm{HgSO}_{4}$ and $\mathrm{BaCO}_{3}$, which was employed by Young [1934b]. Treatment of the extract with a mixture of regenerated, washed and dried carbonaceous zeolite and 'M.P.D. Resin' is more efficient than successive treatments with the two materials separately. With this technique, however, the adsorbing materials cannot be regenerated.

$250 \mathrm{~g}$. or more of the carbonaceous zeolite are shaken gently at intervals for a period of $1 \mathrm{hr}$. with 2 vols. of $2 \mathrm{~N} \mathrm{HCl}$, filtered on a Buchner funnel and washed on the funnel with a total volume of approximately $5 \mathrm{l}$. of distilled water. The final washings should be neutral to litmus. This regenerated, washed cation exchange material is dried at $100^{\circ}$ and sieved so that the particles are of $20 / 40$ mesh sieve size. The 'M.P.D. Resin' is treated in a similar way, but with $2 \mathrm{~N} \mathrm{NH}_{4} \mathrm{OH}$ instead of $\mathrm{HCl}$. At least 1 l. of hot distilled water should be used to wash this reagent, in order to remove excess $m$-phenylene diamine which is liable to be present and which, if not removed completely, gives a blank reading with $\mathrm{HIO}_{4}$. These two regenerated, washed, dried and sieved materials are mixed in equal parts by weight; this preparation will be called the 'adsorbent'.

$15 \mathrm{~g}$. of adsorbent are introduced into a tube approximately $20 \mathrm{in}$. by $\frac{7}{16}$ in., narrowed at the bottom to approximately $\frac{3}{16}$ in., and fitted with a small piece of rubber tubing carrying a glass tip and provided with a screw clip. The material is kept in position in the tube with a loosely packed plug of glass-wool. Before being treated with the tissue extract, the adsorbent is washed with a total volume of approximately $100 \mathrm{ml}$. of distilled water. The final washings must give no blank when allowed to react with $5 \mathrm{ml}$. $0.01 \mathrm{M} \mathrm{HIO}_{4}$ for $10 \mathrm{~min}$. at room temperature. To prevent the formation of air bubbles in the column, which would impede the passage of liquid, the tube should contain distilled water into which the adsorbent is poured, the level of the liquid being kept above the top of the adsorbent. After the adsorbent has been washed sufficiently, the supernatant liquid from the yeast treatment is poured into the tube and allowed to drip through the column at a rate such that the whole of the liquid passes through in approximately $90 \mathrm{~min}$. When the liquid has passed through completely, the first $10 \mathrm{ml}$. portion of the yeast washings is poured into the tube, and the rate of flow adjusted so that this liquid passes through in approximately $15 \mathrm{~min}$. The tube containing the column of adsorbent is sucked dry on a filter pump, and then a second $10 \mathrm{ml}$. portion of yeast washings is allowed to drip through the column, which is then sucked dry. The column is washed with the help of suction with 15 successive $5 \mathrm{ml}$. portions of distilled water. This amount of washing is found to be necessary and sufficient to obtain quantitative recovery of $1 \mathrm{mg}$. of added inositol.

The assumption has been made that the only $\mathrm{HIO}_{4}$ reacting substances which are not removed from yeastfermented muscle extracts by the adsorbent mixture are inositol and glycerol:

Oxidation with $\mathrm{HIO}_{4}$. At the suggestion of Prof. $\mathrm{H}$. Raistrick, we investigated the possibility of estimating inositol by oxidation with $\mathrm{HIO}_{4}$. Malaprade [1928 $a, b$, 1934] found that polyhydroxy alcohols were oxidized quantitatively by $\mathrm{HIO}_{4}$ at room temperature. Fleury \& Joly $[1937 a, b]$ used periodate for the estimation of inositol both in pure solution and in the presence of glucose, but under the conditions used by them the oxidation, when allowed to go to completion, used up much more periodate than was to be expected from the equation

$$
\mathrm{C}_{6} \mathrm{H}_{6}(\mathrm{OH})_{6}+6 \mathrm{HIO}_{4}=6 \mathrm{HIO}_{3}+6 \mathrm{H} . \mathrm{COOH} \text {, }
$$

and they came to the conclusion that secondary reactions occurred.

By allowing the reaction to go to completion at low temperatures $\left(6-8^{\circ}\right)$, we have found that the utilization of $\mathrm{HIO}_{4}$ is quantitative. Formic acid, determined by titrating to $\mathrm{pH} 5.5$ with $0.01 \mathrm{~N} \mathrm{NaOH}$, with a mixture of chlorophenol red and bromocresol green as indicator, has been produced to the extent of about $90 \%$ of the theoretical amount by the time the utilization of $\mathrm{HIO}_{4}$ has reached the theoretical figure. Thereafter no more formic acid is formed. Some typical results for the reaction between $\mathrm{HIO}_{4}$ and inositol in varying concentrations at 8 and $30^{\circ}$ are given in Fig. 1.

Differential oxidation of inositol and of glycerol by $\mathrm{HIO}_{4}$. After the removal of glucose from muscle extracts by fermentation with yeast, small amounts of glycerol remain. Some, no doubt, is extracted from the muscle and an 
amount equivalent to approximately $4 \%$ of the glucose fermented is produced by fermentation. Attempts to remove glycerol by making use of its slight solubility in ether, its reported solubility in dry ethyl acetate, and its fermentation by Bacillus proteus, all failed. Glycerol, in concentrations of $0.2-0.9 \mathrm{mg} . / 100 \mathrm{ml}$. solution, is, however, oxidized completely and quantitatively by $2 \mathrm{ml} .0 .01 \mathrm{M}$ $\mathrm{HIO}_{4}$ at $8^{\circ}$ in $90 \mathrm{~min}$.

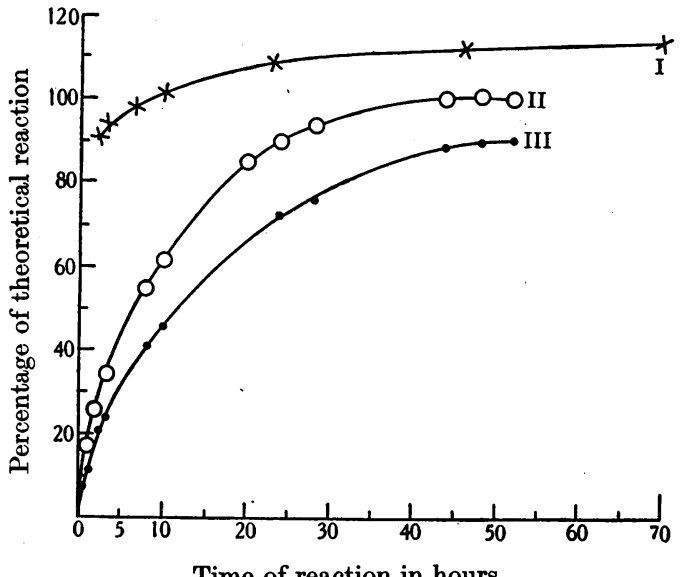

Time of reaction in hours

Fig. 1. Reaction of inositol with periodic acid. Extent to which the reaction

is followed.

$$
\mathrm{C}_{6} \mathrm{H}_{6}(\mathrm{OH})_{6}+6 \mathrm{HIO}_{4}=6 \mathrm{H} \cdot \mathrm{COOH}+6 \mathrm{HIO}_{3}
$$

I, $1 \mathrm{mg}$. inositol $/ 10 \mathrm{ml} .+5 \mathrm{ml} .0 .01 \mathrm{M} \mathrm{HIO}_{4}$ at $30^{\circ}$.

II, $1 \mathrm{mg}$. inositol $/ 100 \mathrm{ml}$. $+10 \mathrm{ml} .0 .01 \mathrm{M} \mathrm{HIO}_{4}$ at $8^{\circ}$

III, $1 \mathrm{mg}$. inositol $/ 100 \mathrm{ml}$. $+5 \mathrm{ml}$. $0.01 \mathrm{M} \mathrm{HIO}_{4}$ at $8^{\circ}$.

The percentage oxidation of glycerol $(0.8 \mathrm{mg} . / 100 \mathrm{ml}$.) by $2 \mathrm{ml} .0 .01 \mathrm{M} \mathrm{HIO}_{4}$ at $8^{\circ}$ at intervals up to $100 \mathrm{~min}$. is as follows:

$\begin{array}{lllllllll}\text { Time in min. } & 20 & 30 & 40 & 60 & 70 & 80 & 90 & 100\end{array}$ $\begin{array}{lllllllll}\% \text { oxidation } & 53.0 & 68.6 & 79.8 & 95.6 & 98.0 & 100 & 100 & 100\end{array}$

The time for complete oxidation of glycerol depends on the temperature at which the reaction is carried out and on the concentration of both glycerol and $\mathrm{HIO}_{4}$ : e.g. at $6^{\circ}$ $1 \mathrm{mg}$. of glycerol in $10 \mathrm{ml}$. water is completely oxidized by $3.0 \mathrm{ml} .0 .01 \mathrm{M} \mathrm{HIO}_{4}$ in $15 \mathrm{~min}$.

Concentrations of inositol of $0.5-2.5 \mathrm{mg} . / 100 \mathrm{ml}$. react to the extent of $1 \cdot 7-2.2 \%$ with $2.0 \mathrm{ml} .0 .01 \mathrm{M} \mathrm{HIO}_{4}$ at $8^{\circ}$ in $90 \mathrm{~min}$. It was therefore necessary to determine $(a)$ the total $\mathrm{HIO}_{4}$-reacting material (inositol plus glycerol) in $100 \mathrm{ml}$. of solution treated with $10 \mathrm{ml} .0 .01 \mathrm{M} \mathrm{HIO}_{4}$ at $8^{\circ}$ for $48 \mathrm{hr}$., and $(b)$ the material reacting under the same conditions of concentration and temperature with $2 \mathrm{ml}$. $0.01 \mathrm{M} \mathrm{HIO}_{4}$ in $90 \mathrm{~min}$. (b) includes the whole of the glycerol and approximately $2 \%$ of the total inositol. Thus the difference between $(a)$ and $(b)$ multiplied by 1.02 gives the inositol content of the solution.

Absence of $\mathrm{HIO}_{4}$-reducing substances other than glycerol and inositol from fermented effluent. There is support for the assumption, that glycerol and inositol are the only $\mathrm{HIO}_{4}$ reacting substances left after fermentation and adsorption, in the fact that the glycerol content of the purified extracts, calculated from the $\mathrm{HIO}_{4}$ reduced under the conditions stated above, is identical with that calculated from the formaldehyde formed, estimated as the dimedone derivative. The only other possible substances which would react with $\mathrm{HIO}_{4}$ are amino-acids. Tests for $\mathrm{NH}_{3}$ production (from $\beta$-hydroxy amino-acids) with $\mathrm{HIO}_{4}$ in strongly alkaline solution in a Conway unit were always negative, as also were tests for amino- $\mathrm{N}$ by formol titration.

Estimation of free inositol. The effluent from the adsorption procedure is made up to $200 \mathrm{ml}$. in a graduated flask and $100 \mathrm{ml}$. withdrawn. Both portions are cooled to $8^{\circ}$. To one portion are added $10 \mathrm{ml} .0 .01 \mathrm{M} \mathrm{HIO}_{4}$ (also at $8^{\circ}$ ) and the reaction allowed to proceed for $48 \mathrm{hr}$. To the other portion, $2 \mathrm{ml}$. $\mathrm{HIO}_{4}$ are added and the reaction is allowed to proceed at $8^{\circ}$ for $90 \mathrm{~min}$. If a temperature other than $8^{\circ}$ is selected the time relationships for oxidation of both glycerol and inositol at this temperature must be determined. The reaction is stopped in both cases by adjusting the $\mathrm{pH}$ to approximately 6.5 by the addition of $5 \mathrm{ml}$. phosphate buffer $\left(12 \mathrm{~g}\right.$. $\mathrm{Na}_{2} \mathrm{HPO}_{4} \cdot 12 \mathrm{H}_{2} \mathrm{O}$ and $20 \mathrm{ml}$. $\mathrm{N}$ $\mathrm{H}_{2} \mathrm{SO}_{4} / 100 \mathrm{ml}$.), followed by $5 \mathrm{ml} .5 \% \mathrm{KI}$ solution. After 5 min. the $I_{2}$ liberated is titrated with approximately $0.004 \mathrm{~N} \mathrm{Na}_{2} \mathrm{~S}_{2} \mathrm{O}_{3}$ with $1 \%$ soluble starch in saturated $\mathrm{NaCl}$ as indicator, the end-point being stabilized by the addition of a few drops of saturated $\mathrm{NaHCO}_{3}$ solution. $1 \mathrm{mg}$. inositol contained in $100 \mathrm{ml}$. distilled water is also allowed to react with $10 \mathrm{ml} .0 .01 \mathrm{M} \mathrm{HIO}_{4}$ for $48 \mathrm{hr}$. at $8^{\circ}$, and the excess $\mathrm{HIO}_{4}$ titrated as above.

The $\mathrm{HIO}_{4}$ reduced is obtained from the difference between the titration of the purified tissue extract after reaction with $\mathrm{HIO}_{4}$ and the blank titration obtained with the $\mathrm{HIO}_{4}$ alone.

Let $x=\mathrm{HIO}_{4}$ reduced in terms of $0.004 \mathrm{~N} \mathrm{Na} \mathrm{Na}_{2} \mathrm{O}_{3}$ in $48 \mathrm{hr}$. at $8^{\circ}$,

$y=\mathrm{HIO}_{4}$ reduced in terms of $0.004 \mathrm{~N} \mathrm{Na} \mathrm{N}_{2} \mathrm{O}_{3}$ in 90 min. at $8^{\circ}$,

$z=\mathrm{HIO}_{4}$ reduced by $1 \mathrm{mg}$. inositol in $48 \mathrm{hr}$. at $8^{\circ}$.

The approximate inositol content in $\mathrm{mg}$. of half the extract is given by $(x-y) / z$ which should be multiplied by 1.02 (see above).

Estimation of 'combined inositol'. For the estimation of the water-soluble combined inositol, the extract is hydrolyzed with acid [Woolley, 1941 b]. Both water-soluble fractions (i.e. 'free' and 'combined') are determined in the same sample of tissue, with twice as much tissue as in the procedure outlined above. Before fermentation, the extract is made to $50 \mathrm{ml}$., and one-half is refluxed for $6 \mathrm{hr}$. with $\mathrm{HCl}$ (final concn. $18 \% \mathrm{HCl}$ ). The $\mathrm{HCl}$ is removed by distillation under reduced pressure, and the contents of the flask are washed out with distilled water to give a total volume of approximately $25 \mathrm{ml}$. and then neutralized by the dropwise addition of $\mathrm{N} \mathrm{NaOH}$.

\section{Experimental diets}

Albino rats were put on an experimental diet, containing only small amounts of inositol, at 6 weeks of age and were in good condition when killed after an experimental period of $16 \frac{1}{2}$ months. The diet consisted of casein (A/E, Glaxo), $24 \%$; sucrose, $67.5 \%$ (replaced by maize dextrin, after $13 \frac{1}{2}$ months on diet, for 2 months and by rice starch for last month); McCollum's salt mixture (185), $4 \%$; wheatgerm oil, $2 \%$; dried yeast (Torula utilis, $95 \%$ dry matter, containing not more than $2.7 \mathrm{mg}$. inositol $/ \mathrm{g}$.), $2.5 \%$, in- 
creased to $5 \%$ after 2 months on the diet; ascorbic acid $2.5 \mathrm{mg}$. daily; vitamin A approximately 22.5 r.v. daily and vitamin D approximately $4 \cdot 5 \mathrm{I}$.U. daily (both contained in 2 drops of Radiostoleum diluted with peanut oil). Between 8 and $12.5 \mathrm{~g}$. of this diet, mixed to a thick paste with water, were fed daily to each rat.

\section{RESULTS}

\section{Inositol content of rat tissues}

Table 1 contains the mean results of analyses of the tissues of four rats for water-soluble inositol, free and total (i.e. including combined).

Table 1. Inositol content of rat tissues

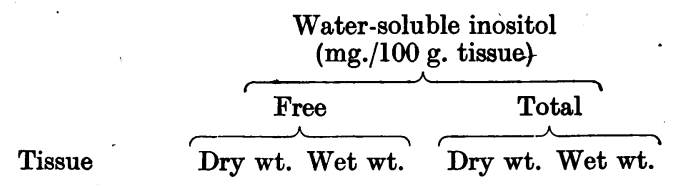

(a) Rats given $5 \mathrm{mg}$. inositol/day

$\begin{array}{lllll}\text { Skeletal muscle } & 49 \cdot 3 & 12 \cdot 9 & 81 \cdot 2 & 21 \cdot 3 \\ \text { Liver } & 85 \cdot 2 & 24 \cdot 8 & 178 & 52 \cdot 1 \\ \text { Heart } & 141 \cdot 3 & 34 \cdot 3 & 186 & 45 \cdot 3 \\ \text { Brain } & 241 & 55 \cdot 8 & 286 & 67 \cdot 0 \\ \text { Kidney } & 328 & 88 \cdot 0 & 456 & 123\end{array}$

(b) Rats given no extra inositol

\begin{tabular}{|c|c|c|c|c|}
\hline Skeletal muscle & $24 \cdot 0$ & $\begin{array}{r}6 \cdot 3 \\
25.5\end{array}$ & $\begin{array}{r}76 \cdot 2 \\
174\end{array}$ & $\begin{array}{l}18 \cdot 3 \\
50.3\end{array}$ \\
\hline $\begin{array}{l}\text { Liver } \\
\text { Heart }\end{array}$ & & & & \\
\hline Brain & 169 & $37 \cdot 8$ & 295 & $66 \cdot 1$ \\
\hline Kidney & 316 & $79 \cdot 5$ & 426 & 113 \\
\hline
\end{tabular}

Our values for the total water-soluble inositol contents of rat tissues are of the same order as those found by other workers, including those recently obtained by Williams et al. [1941], with a microbiological method, on tissue autolysates. The proportions of free to total water-soluble inositol are also of the same order as those obtained by Woolley [1942], who also used a microbiological method.

It will be seen that there is no important difference between the values for the total water-soluble inositol for the rats receiving the inositol-deficient diet, and those with added inositol. It thus appears that rats are able to synthesize inositol, which confirms the earlier work of Needham [1924]. Woolley [1942] also showed that mice could synthesize inositol in the gut if the diet was not deficient in pantothenic acid.

\section{SUMMARY}

1. A chemical method is described for the estimation of inositol in animal tissues. This possesses advantages over earlier methods in that the time taken for an estimation is considerably reduced, the method of extraction of inositol from the tissues improved, the tedious precipitation procedures replaced by treatment with ion exchange materials, and the inositol finally estimated in solution by reaction with $\mathrm{HIO}_{4}$ without isolation of the inositol.

2. Both free and total water-soluble inositol were determined in the kidney, heart, liver, brain and skeletal muscle of control rats, and of rats receiving a daily supplement of $5 \mathrm{mg}$. inositol. No appreciable difference was found between the total watersoluble inositol contents of the tissues in the two groups of rats.

\section{REFERENCES}

Danileffski, B. [1884]. Bull. Soc. chim. Paris, 41, 255.

Fleury, P. \& Joly, M. [1937a]. J. pharm: chim. 26, 341.

\section{[1937b]. J. pharm. chim. 26, 397.}

Folch, J. \& Woolley, D. W. [1942]. J. biol. Chem. 142, 963.

Gregory, R. A. [1935]. Biochem. J. 29, 2798.

Malaprade, L. [1928a]. C.R. Acad. Sci., Paris, 186, 238.

__ [1928b]. Bull. Soc. chim. Fr. (4th ser.), 43, 683. [1934]. Bull. Soc. chim. Fr. (5th ser.), 1, 833.

Needham, J. [1923]. Biochem. J. 17, 422.

- [1924]. Biochem. J. 18, 891.

- [1926]. Ergebn. Physiol. 25, 1.

Platt, B. S. \& Glock, G. E. [1942]. Biochem. J. 36, Proc. xviii.

Rapoport, S. [1940]. J. biol. Chem. 135, 403.
Rosenberger, F. [1908a]. Hoppe-Seyl. Z. 56, 373.

- [1908b]. Hoppe-Seyl. Z. 57, 464.

- [1910]. Hoppe-Seyl. Z. 64, 341.

West, E. S. \& Petersen, V. L. [1932]. Biochem. J. 26, 1720.

Williams, R. J., Stout, A. K., Mitchell, H. K. \& McMahan, J. R. [1941]. Studies on the Vitamin Content of Tissues, 1. University of Texas Publication No. 4137, University of Texas, Austin, Texas.

Winter, L. B. [1934]. Biochem. J. 28, 6.

- [1940]. Biochem. J. 34, 249.

Woolley, D. W. [1941 a]. J. biol. Chem. 139, 29.

[1941b]. J. biol. Chem. 140, 453.

- [1942]. J. exp. Med. 75, 277.

Young, L. [1934a]. Biochem. J. 28, 1428.

$-[1934 b]$. Biochem. J. 28, 1435. 